\title{
PM emission in the exhaust gas of SI engines fed with petrol or LPG
}

\author{
The paper presents measurements of PM emission in the exhaust gas of a gasoline fueled SI engine alternatively fueled \\ with LPG. The research was performed on a 170.A1 engine using the Dekati ELPI+ PM analyzer and Micro Diluter \\ 6100 (a micro-dilution tunnel). The author also measured the concentration of exhaust gaseous components with the \\ use of Horiba MEXA 1500GH analyzer. The author compared the PM concentration and size distribution in the exhaust \\ gas for both fuels.
}

Key words: SI engine, exhaust gas emissions, particulate matter, nanoparticles, petrol, LPG

\section{Emisja cząstek stałych w spalinach silnika ZI zasilanego benzyną lub mieszaniną propanu i butanu}

\author{
W artykule przedstawiono pomiary emisji czastek statych (PM) w spalinach silnika ZI zasilanego benzyna albo skro- \\ plona mieszanina propanu i butanu. Badania przeprowadzono na silniku 170.A1 z użyciem analizatora czastek statych \\ Dekati ELPI+ wyposażonego w minitunel rozcieńczajacy Micro Diluter 6100. Równocześnie dokonano pomiaru stężenia \\ gazowych składników spalin za pomoca analizatora Horiba MEXA 1500GH. Zmierzono stężenie oraz rozkład wielkości \\ i liczbę cząstek stałych $w$ spalinach, a następnie porównano uzyskane wyniki dla obu paliw. \\ Słowa kluczowe: silnik ZI, emisja spalin, cząstki stałe, nanoczastki, benzyna, LPG
}

\section{Introduction}

In a continuous strife to reduce the environmental impact of combustion engines new research problems and technical issues arise. Environmental standards legislation for the manufacturers of engines and vehicles is based on the analysis of the existing hazards for human health and life. The next step is creating the 'ecological' expectations from the new standard. An introduction of a standard should be preceded by an analysis of the technical possibilities of its realization in the future. To this end, the theoretical and experimental research of combustion engines related to the exhaust emissions is conducted in all automotive industry research centers including strictly scientific institutions.

One of the exhaust components that have recently drawn significant attention is particulate matter. The emission limits of PM are chiefly related to diesel engines. Manufacturers of these engines were forced to apply measures reducing the PM emission such as combustion control systems and diesel particulate filters.

Thus far, spark ignition engines were not seen as a source of significant PM emission. The problem was first indicated for direct injection spark ignition engines, in which this fueling system may generate a significant amount of PM in the exhaust gas.

Due to the increasingly stringent emission standards, spark ignition engines are also controlled for the PM emission. The PM emission limits for spark ignition engines are only related to direct injected engines. In the currently applicable Euro 6 standard, PM emission limits are not provided for other gasoline engine types [1].

Spark ignition engines in their base version are fueled with gasoline but there exist generally known alternative fuels for these engines such as liquefied petroleum gas (LPG), natural gas or, recently, hydrogen. The emission of PM (mass emission) in the exhaust gas of this type is much

\section{Wstęp}

W związku z nieustannym dążeniem do zmniejszenia szkodliwego wpływu silników spalinowych na środowisko naturalne, pojawiają się nowe problemy badawcze $\mathrm{i}$ techniczne związane $\mathrm{z}$ tym zagadnieniem. Ustawodawstwo dotyczące ekologicznych norm, które obowiązują producentów silników i pojazdów samochodowych opiera się na rozeznaniu istniejących zagrożeń dla zdrowia i życia człowieka. Następnym krokiem jest sformułowanie oczekiwań ze „strony ekologicznej” w odniesieniu do kolejnego limitu dotyczącego emitowanych szkodliwych substancji. Wprowadzenie znowelizowanej normy jest, a przynajmniej powinno być, poprzedzone rozpoznaniem technicznych możliwości jej realizacji w przyszłości. $Z$ tego powodu badania teoretyczne i eksperymentalne silników spalinowych związane z emisją szkodliwych związków w spalinach prowadzone są we wszystkich ośrodkach przemysłu silnikowego i placówkach naukowych.

Jednym ze składników spalin, który w ostatnich latach znalazł się w centrum zainteresowania są cząstki stałe. Limity emisji PM dotyczą zasadniczo silników o zapłonie samoczynnym. Producenci tych silników zostali zobligowani do zastosowania środków zmniejszających emisję PM, wśród których, poza sterowaniem procesem spalania w cylindrze, należy wymienić stosowanie filtra cząstek stałych w układzie wylotowym.

Dotychczas silniki ZI nie były postrzegane jako źródło istotnej emisji PM. Po raz pierwszy problem zasygnalizowano w silnikach ZI z bezpośrednim wtryskiem paliwa, w których ten system spalania może generować znaczącą emisję PM w spalinach.

W związku z ogólnie zaostrzającymi się normami emisji spalin, również silniki ZI podlegają ograniczeniom związanym z zawartością cząstek stałych $\mathrm{w}$ spalinach. Limit masy cząstek stałych dla silników z zapłonem iskrowym 
lower compared to diesel engines, which was confirmed by the tests on direct injected gasoline engines performed by Chair of Combustion Engines at Cracow University of Technology [2]. The tests were conducted using Horiba TEOM 1105 analyzer. The analyzer designed for the measurement of PM in diesel exhaust gas did not provide reliable assessment of the PM emission from the gasoline engine due to its insufficient measurement resolution. The resolution was too low for the PM mass concentration and the PM smaller diameter in the gasoline exhaust gas compared to that of a diesel engine.

Because of its characteristic size, particulate matter can pass through the human respiratory system to the bloodstream, potentially leading to a variety of circulatory system conditions. Particularly hazardous are the nanoparticles (nPM) of the diameter in the range of $1-100 \mathrm{~nm}$.

Thus far, the measurement results provided in literature as well as the validation of the measurements of nPM adopted the particle size of approx. 5-6 $\mathrm{nm}$ as the lower boundary diameter value [6-8]. Lower values of the diameter [4] pertained to the molecules of the elemental or organic carbon, carbon monoxide, volatile polycyclic aromatic hydrocarbons (to some extent) or sulfates. In recently published works, PM test results have appeared covering the particles of the diameter lower than $5 \mathrm{~nm}$ [9]. We can conclude that as the measurement methods and the equipment improve [5] particular attention will be drawn to particles of this size.

This paper describes research on the determination of the influence of type of fuel on the PM emission in spark ignition engines. The research was carried out in the chair of Combustion Engines at Cracow University of Technology.

\section{Research object and equipment}

The research object was a four cylinder $0.9 \mathrm{dm}^{3}$ spark ignition 170.A1 engine fitted with a gasoline and a liquefied petroleum gas (LPG) fueling system. The engine was installed on a test bed with an electric brake.

The stand was fitted with an exhaust gas sampling system for the PM measurement. Dekati ELPI+ particle counter was used to which the exhaust gas was fed through a micro dilution tunnel (Micro Diluter 6100).

The Dekati ELPI+ (Electrical Low Pressure Impactor) analyzer (Fig. 1) [3] measures the PM concentration and PM
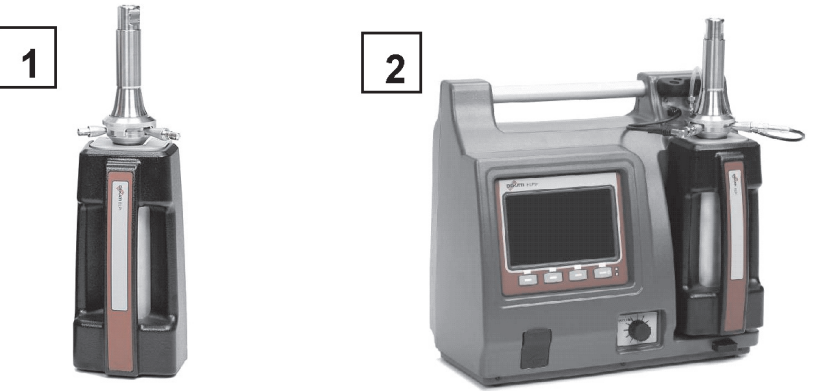

Fig. 1. Particulate matter analyzer ELPI+: 1 - impactor, 2 - general view [3]

Rys. 1. Analizator cząstek statych ELPI+: 1 -impaktor, 2 -widok ogólny [3] dotyczy obecnie jedynie silnika z bezpośrednim wtryskiem paliwa. W obowiązującej obecnie normie Euro 6 nadal nie przewiduje się ograniczeń emisji PM dla pozostałych typów silników ZI [1].

Silniki ZI w podstawowej wersji zasilane są benzyną, ale istnieją powszechnie znane układy zasilania tych silników gazowymi paliwami alternatywnymi, takimi jak: skroplona mieszanina propanu i butanu (LPG), gaz ziemny lub ostatnio wodór. Emisja PM (masa) w spalinach silników tego typu jest znacznie mniejsza niż w spalinach silników ZS, co potwierdziły również wykonane wcześniej w Zakładzie Silników Spalinowych Politechniki Krakowskiej badania silnika ZI z bezpośrednim wtryskiem benzyny [2]. Badania przeprowadzono z użyciem analizatora Horiba TEOM 1105. Analizator tego typu przewidziany do pomiarów emisji PM w spalinach silników ZS nie umożliwiał wiarygodnej oceny emisji cząstek stałych dla silnika ZI ze względu na rozdzielczość pomiarową. Była ona zbyt mała wobec mniejszej koncentracji masy i mniejszej średnicy PM w spalinach silnika ZI w porównaniu z emisją w spalinach silnika ZS.

Wymiary PM stwarzają szczególną możliwość przedostawania się ich drogą oddechową do krwioobiegu człowieka, powodując potencjalne zagrożenie np. chorobami układu krążenia. Jako szczególnie niebezpieczne postrzegane są tu nanocząstki (nPM) o średnicy z przedziału 1-100 nm.

$\mathrm{W}$ znanych $\mathrm{z}$ literatury pomiarach i weryfikacji emisji nPM przyjmowana była dotychczas jako dolna, graniczna średnica cząstki wartość około 5-6 nm [6-8]. Mniejsze wartości średnicy [4] dotyczyły molekuł m.in. elementarnego lub organicznego węgla, tlenku węgla, częściowo lotnych wielopierścieniowych węglowodorów aromatycznych, siarczanów. W ostatnio opublikowanych pracach pojawiły się jednak wyniki badań emisji PM obejmujących również cząstki o średnicy mniejszej niż 5 nm [9]. Można sądzić, że wraz z rozwojem metod pomiarowych i aparatury badawczej [5] szczególna uwaga będzie zwrócona na cząstki o tych wymiarach.

W niniejszym artykule przedstawiono badania wykonane w Zakładzie Silników Spalinowych Politechniki Krakowskiej dotyczące określenia wpływu rodzaju paliwa na emisję cząstek stałych w spalinach silnika ZI.

\section{Obiekt badań i aparatura pomiarowa}

Jako obiekt badań wybrano czterocylindrowy silnik 170.A1 o objętości skokowej $0,9 \mathrm{dm}^{3} \mathrm{z}$ zapłonem iskrowym, wyposażony w układ zasilania benzyną oraz układ zasilania skroploną mieszaniną propanu i butanu (LPG). Silnik zamontowano na stanowisku badawczym z hamulcem elektrycznym.

Stanowisko wyposażono w układ poboru próbek spalin do analizy emisji cząstek stałych. Wykorzystano licznik cząstek stałych Dekati ELPI+, do którego spaliny doprowadzono przez mikrotunel rozcieńczający Micro Diluter 6100.

Analizator Dekati ELPI+ (Electrical Low Pressure Impactor) (rys. 1) [3] umożliwia pomiar stężenia i rozkładu wielkości cząstek stałych w zakresie od $6 \mathrm{~nm}$ do $10 \mu \mathrm{m}$ z częstotliwością próbkowania $10 \mathrm{~Hz}$. Zakres wielkości cząstek jest podzielony na 14 przedziałów, których specyfikację przedstawiono $\mathrm{w}$ tabeli 1 . 
Table 1. Ranges of nominal diameters of PM measured by ELPI+ analyzer [3]

Tabela 1. Przedziały nominalnych średnic czastek stałych PM mierzonych przez analizator ELPI+ [3]

\begin{tabular}{|c|c|c|c|c|c|c|c|c|c|c|c|c|c|c|}
\hline & \multicolumn{10}{|c|}{ Number of diameter interval } \\
\cline { 2 - 14 } & 1 & 2 & 3 & 4 & 5 & 6 & 7 & 8 & 9 & 10 & 11 & 12 & 13 & 14 \\
\hline Ranges of & 0.006 & 0.017 & 0.030 & 0.060 & 0.108 & 0.170 & 0.260 & 0.400 & 0.640 & 1.00 & 1.60 & 2.50 & 4.40 & 6.80 \\
diameters & - & - & - & - & - & - & - & - & - & - & - & - & - & - \\
{$[\mu \mathrm{m}]$} & 0.010 & 0.022 & 0.042 & 0.080 & 0.140 & 0.210 & 0.320 & 0.510 & 0.800 & 1.30 & 2.00 & 3.30 & 5.50 & 8.20 \\
\hline
\end{tabular}

size distribution in the range from $6 \mathrm{~nm}$ to $10 \mu \mathrm{m}$ with the sampling resolution of $10 \mathrm{~Hz}$. The $\mathrm{PM}$ size range is divided into 14 intervals specified in Table 1.

The working principle of the analyzer is based on initial charging of the flowing PM with an electrical charge and then measuring the charge of the particles accumulated on the individual stages of the cascade of 14 electrically insu-

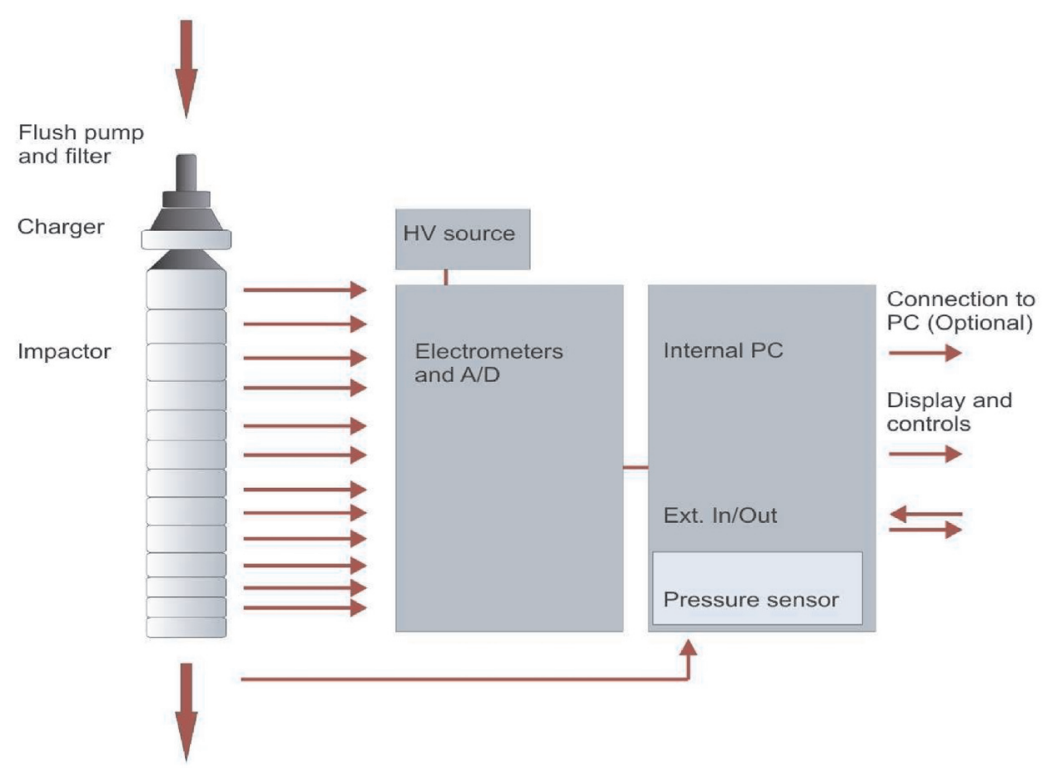

Vacuum pump

Fig. 2. Schematics of the measurement system of the PM analyzer ELPI+ [3]

Rys. 2. Schemat uktadu pomiarowego analizatora czastek statych ELPI+ [3]
Zasada pracy analizatora opiera się na wstępnym ładowaniu znanym ładunkiem elektrycznym przepływającego strumienia cząstek stałych, a następnie pomiarze ładunku cząstek zgromadzonych na poszczególnych poziomach kaskady izolowanych elektrycznie 14 półek w tzw. impaktorze. Cząstki stałe są zbierane na poszczególnych półkach odpowiednio do ich średnicy aerodynamicznej i masy. Ładunek mierzony za pomocą układu elektrometrycznego jest wprost proporcjonalny do liczby i masy cząstek zgromadzonych na danej półce. Na podstawie sygnału elektrycznego uzyskuje się informację o ilościowym i masowym stężeniu oraz rozkładzie wielkości cząstek stałych w badanym strumieniu spalin. Schemat ideowy układu pomiarowego ELPI przedstawia rysunek 2. Zakres pomiarowy analizatora odpowiada wymaganiom prowadzonych badań z uwzględnieniem szczególnie interesującego przedziału średnic najmniejszych cząstek stałych, tj. 6-100 nm.

Schemat toru pomiarowego emisji cząstek stałych z minitunelem rozcieńczającym MD $6100 \mathrm{i}$ analizatorem stężenia gazowych składników spalin Horiba MEXA 1500GH przedstawiono na rysunku 3.

\section{Procedura badań}

Badania silnika 170.A1 wykonano przy prędkości obrotowej wału korbowego $\mathrm{n}=$ 3000 1/min, dla dwóch wartości momen- lated shelves (the impactor). The particles are collected on the individual shelves proportionally to their aerodynamic diameter and mass. The charge measured by the electrometric system is directly proportional to the number and mass of the particles accumulated on a given shelf. Based on the electrical signal we obtain information on the number and mass concentration as well as the distribution of PM in the tested gas flow. The diagram of the ELPI measurement system is shown in Fig. 2. The measurement range of the analyzer meets the requirements of the performed tests including the particularly interesting range of diameters of the smallest PM i.e. 6-100 nm.

Schematics of the measurement line of the PM emission with the MD 6100 micro dilution tunnel and the Horiba MEXA $1500 \mathrm{GH}$ analyzer (concentration of gaseous components) has been shown in Fig. 3.

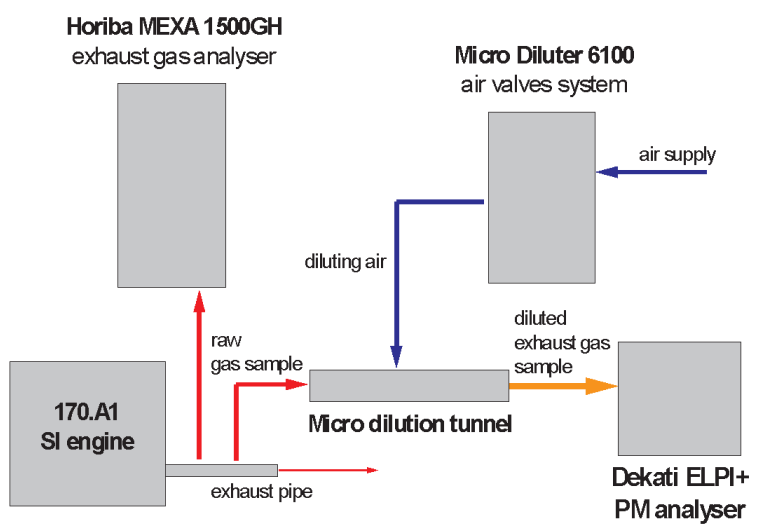

Fig. 3. Diagram of the PM measurement line with the micro dilution tunnel (MD 6100)

Rys. 3. Schemat toru pomiarowego czastek stałych PM z mini-tunelem rozcieńczajacym MD 6100 


\section{Research procedure}

The research on the 170.A1 engine was performed at the engine speed of $\mathrm{n}=3000 \mathrm{1} / \mathrm{min}$ for two values of torque: 10 $\mathrm{N} \cdot \mathrm{m}$ and $45 \mathrm{~N} \cdot \mathrm{m}$ representing the state of low and medium loads. The engine was fueled with gasoline and then with standard LPG. Through the ELPI+ analyzer the author recorded the emission of PM. The sampling was done through the MD 6100 dilution mini-tunnel. Since a small flow of particle was expected, the smallest admissible dilution rate of $D_{R}=6.2$ was applied. The engine ran on a stoichiometric mixture for both gasoline and LPG. The values of the PM emission were measured for 5 minutes. Simultaneously, with the Horiba MEXA 1500GH analyzer, the concentrations of the following exhaust gas components were measured: carbon monoxide, carbon dioxide, hydrocarbons, oxygen and nitrogen oxides.

\section{Results}

The results of the PM measurement in the exhaust gas of the 170.A1 engine are presented in Figs 4-11. The scale of the individual tracings, according to the automatic recording of the analyzer, corresponds to the range of the measured

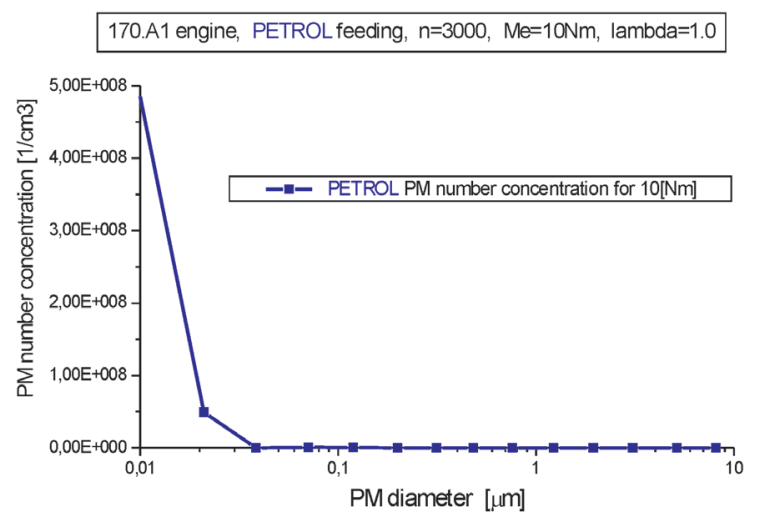

Fig. 4. PM number concentration in the exhaust gas of the 170.A1 engine fueled with gasoline related to the PM size; engine speed $n=3000$ $1 / \mathrm{min}$, load $10 \mathrm{~N} \cdot \mathrm{m}$, air excess coefficient $\lambda=1.0$

Rys. 4. Stężenie liczbowe czastek statych $w$ spalinach silnika 170.A1 zasilanego benzyna w zależności od wielkości czastek; prędkość obrotowa silnika $n=3000 \mathrm{l} / \mathrm{min}$, obcią̇enie $10 \mathrm{~N} \cdot \mathrm{m}$, współczynnik nadmiaru powietrza $\lambda=1,0$

values. Comparative tracings (Fig. 12 and 13) of the particle number, mass concentration and types of fuel were shown in the same scale for all load conditions. The courses shown in this way allowed generating a better picture of the proportions between the PM emissions in individual cases.

Gaseous concentrations of exhaust gas components for individual cases are shown in figures 14-18.

The nature of the curve tracings of the particle number concentration was similar for both engine loads and fuels (Fig. 12). The maximum value of the particle number concentration was for the smallest particles of the diameter of 6-10 $\mathrm{nm}$ represented by points on the abscissa of $0.01 \mu \mathrm{m}$ (measurement range no. 1 of the ELPI+ analyzer) . tu obrotowego: $10 \mathrm{~N} \cdot \mathrm{m}$ i $45 \mathrm{~N} \cdot \mathrm{m}$, reprezentujących stan małego i średniego obciążenia. Silnik zasilano benzyną, a następnie standardową mieszaniną skroplonego propanu $\mathrm{i}$ butanu. Za pomocą analizatora ELPI+ rejestrowano emisję cząstek stałych. Poboru spalin do analizy dokonano przez minitunel rozcieńczający MD 6100. Ze względu na spodziewany niewielki strumień cząstek, zastosowano najmniejszą możliwą do uzyskania wartość stopnia rozcieńczenia $D_{R}=$ $=6,2$. Silnik zasilano mieszanką stechiometryczną zarówno w odniesieniu do benzyny, jak i mieszaniny propanu i butanu. Wartości emisji cząstek stałych mierzono w czasie $5 \mathrm{~min}$. Równolegle za pomocą analizatora Horiba MEXA 1500GH mierzono wartości stężenia gazowych składników spalin: tlenku węgla, dwutlenku węgla, węglowodorów, tlenu oraz tlenków azotu.

\section{Wyniki badań}

Wyniki pomiarów emisji cząstek stałych w spalinach silnika 170.A1 przedstawiono na rysunkach 4-11. Skala poszczególnych wykresów, zgodnie z automatycznym zapisem analizatora, odpowiada zakresowi zmierzonych wartości. Wykresy porównawcze (rys. 12 i 13) liczby cząstek oraz

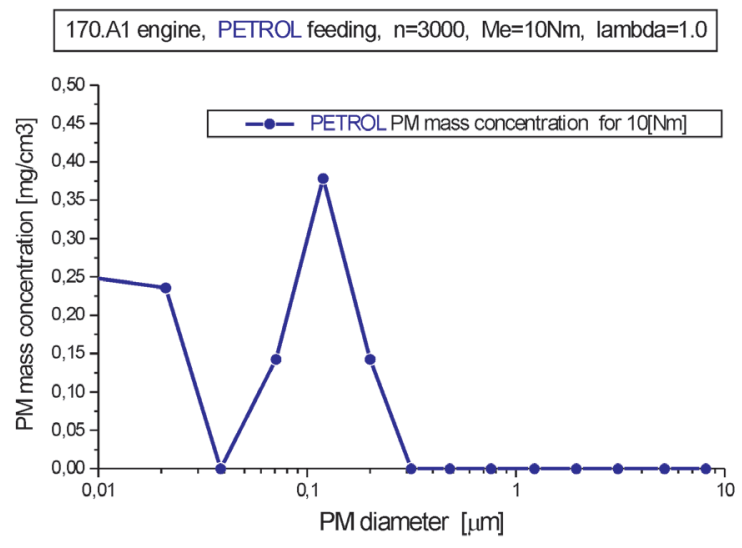

Fig. 5. PM mass concentration in the exhaust gas of the 170.A1 engine fueled with gasoline related to the PM size; engine speed $n=3000$ $1 / \mathrm{min}$, load $10 \mathrm{~N} \cdot \mathrm{m}$, air excess coefficient $\lambda=1.0$

Rys. 5. Stężenie masowe cząstek statych $w$ spalinach silnika 170.A1 zasilanego benzyną w zależności od wielkości cząstek; prędkość obrotowa silnika $n=3000 \mathrm{l} / \mathrm{min}$, obciążenie $10 \mathrm{~N} \cdot \mathrm{m}$, współczynnik nadmiaru powietrza $\lambda=1,0$

masowego stężenia cząstek i rodzajów paliwa wykonano w tej samej skali dla wszystkich stanów obciążenia. Tak zestawione przebiegi pozwoliły na lepsze zobrazowanie proporcji między wartościami emisji PM w poszczególnych przypadkach.

Wartości stężeń gazowych składników spalin dla poszczególnych przypadków przedstawiono na rysunkach 14-18.

Charakter przebiegu krzywych stężenia liczbowego cząstek stałych był podobny dla obu badanych stanów obciążenia silnika i rodzajów paliwa (rys. 12). Maksimum wartości stężenia liczbowego cząstek stałych przypadało dla najmniejszych wielkości cząstek stałych 6-10 nm, reprezentowanych na wykresach przez punkty o odciętej $0,01 \mu \mathrm{m}$ (przedział pomiarowy nr 1 analizatora ELPI+). 


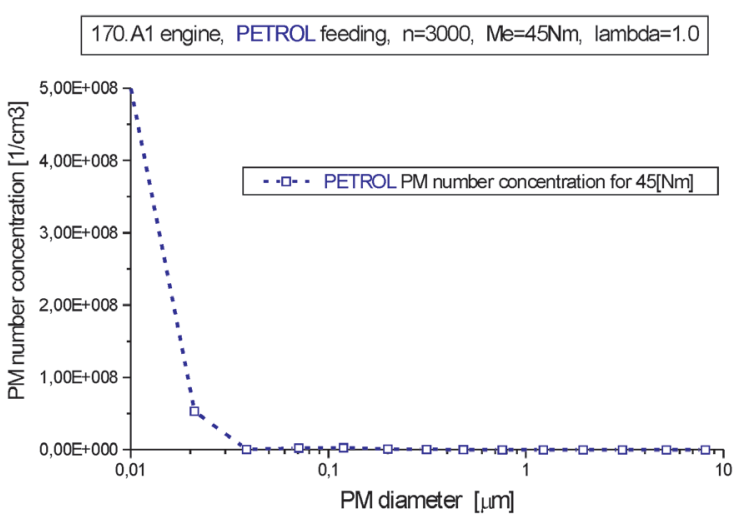

Fig. 6. PM number concentration in the exhaust gas of the 170.A1 engine fueled with gasoline related to the PM size; engine speed $n=3000$ $1 / \mathrm{min}$, load $45 \mathrm{~N} \cdot \mathrm{m}$, air excess coefficient $\lambda=1.0$

Rys. 6. Stężenie liczbowe czastek statych w spalinach silnika 170.A1 zasilanego benzyna w zależności od wielkości cząstek; prędkość obrotowa silnika $n=3000 \mathrm{I} / \mathrm{min}$, obciążenie $45 \mathrm{~N} \cdot \mathrm{m}$, współczynnik nadmiaru powietrza $\lambda=1,0$

\section{A1 engine, LPG feeding, $n=3000, M e=10 \mathrm{Nm}$, lambda=1.0}

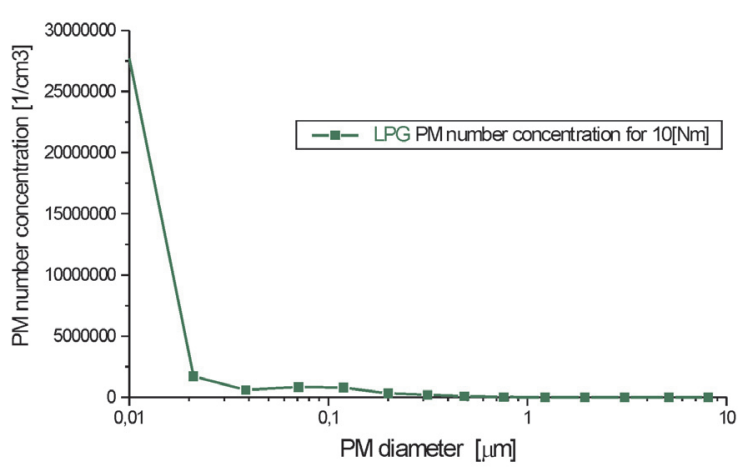

Fig. 8. PM number concentration in the exhaust gas of the 170.A1 engine fueled with LPG related to the PM size; engine speed $n=3000$ $1 / \mathrm{min}$, load $10 \mathrm{~N} \cdot \mathrm{m}$, air excess coefficient $\lambda=1.0$

Rys. 8. Stężenie liczbowe cząstek stałych $w$ spalinach silnika 170.A1 zasilanego mieszanina propanu i butanu w zależności od wielkości cząstek; prędkość obrotowa silnika $n=3000 \mathrm{l} / \mathrm{min}$, obciążenie $10 \mathrm{~N} \cdot \mathrm{m}$, współczynnik nadmiaru powietrza $\lambda=1,0$

The comparison of the curve tracings of the particle mass concentration (Fig. 13) also showed similar shapes for both tested engine loads and fuel types. The difference was in the particle diameters and loads for which the maximum in individual curves occurred.

When fueled with gasoline, the particle mass concentration had the greatest value for the particle diameter of 300 $\mathrm{nm}$ at the load of $45 \mathrm{~N} \cdot \mathrm{m}$.

When fueled with LPG, the particle mass concentration reached the value of approx. $500 \mathrm{~nm}$ at the load of $10 \mathrm{~N} \cdot \mathrm{m}$.

For both fuels (gasoline and LPG) for the particle diameter of approx. $110 \mathrm{~nm}$ a small local maximum of the particle mass concentration occurred (approximately 0.5 $\mathrm{mg} / \mathrm{cm} 3$ ). When fueled with gasoline, this effect occurred at the engine load of $10 \mathrm{~N} \cdot \mathrm{m}$ and when fueled with $\mathrm{LPG}$, this occurred at $45 \mathrm{~N} \cdot \mathrm{m}$.
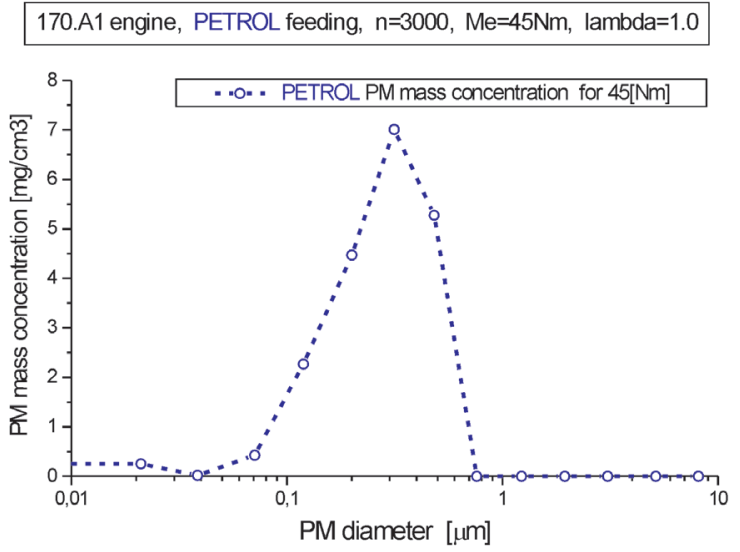

Fig. 7. PM mass concentration in the exhaust gas of the 170.A1 engine fueled with gasoline related to the PM size; engine speed $n=3000$ $1 / \mathrm{min}$, load $45 \mathrm{~N} \cdot \mathrm{m}$, air excess coefficient $\lambda=1.0$

Rys. 7. Stężenie masowe czastek statych $w$ spalinach silnika 170.A1 zasilanego benzyna w zależności od wielkości czątek; prędkość obrotowa silnika $n=3000 \mathrm{l} / \mathrm{min}$, obciążenie $45 \mathrm{~N} \cdot \mathrm{m}$, współczynnik nadmiaru powietrza $\lambda=1,0$

170.A1 engine, LPG feeding, $n=3000, M e=10 \mathrm{Nm}$, lambda=1.0

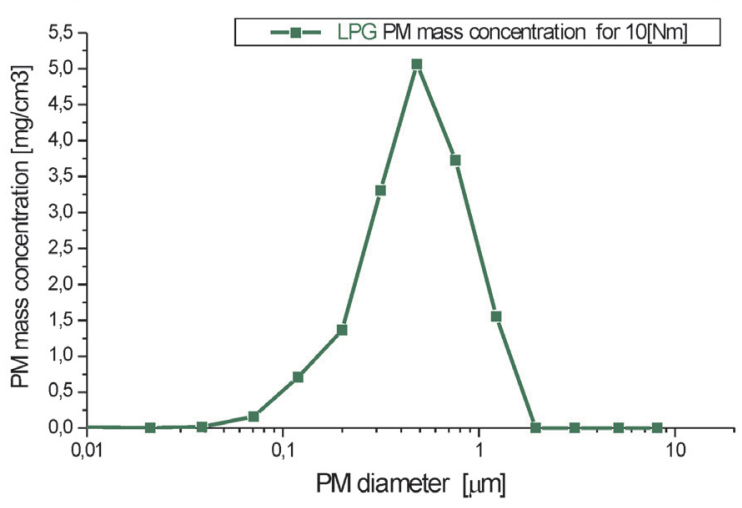

Fig. 9. PM mass concentration in the exhaust gas of the 170.A1 engine fueled with LPG related to the PM size; engine speed $n=30001 / \mathrm{min}$, load $10 \mathrm{~N} \cdot \mathrm{m}$, air excess coefficient $\lambda=1.0$

Rys. 9. Stężenie masowe cząstek statych $w$ spalinach silnika 170.A1 zasilanego mieszanina propanu i butanu w zależności od wielkości czastek; prędkość obrotowa silnika $n=3000 \mathrm{l} / \mathrm{min}$, obciążenie $10 \mathrm{~N} \cdot \mathrm{m}$, współczynnik nadmiaru powietrza $\lambda=1,0$

Porównanie przebiegu krzywych masowego stężenia cząstek stałych (rys. 13) również wykazywało podobieństwo kształtu dla obu badanych stanów obciążenia silnika i rodzajów paliwa. Różnica dotyczyła wielkości cząstek oraz wartości obciążenia, dla którego wystąpiło maksimum na poszczególnych krzywych.

Przy zasilaniu silnika benzyną masowe stężenie PM przyjęło największą wartość dla średnicy cząstek ok. 300 nm przy obciążeniu $45 \mathrm{~N} \cdot \mathrm{m}$.

Przy zasilaniu mieszaniną propanu i butanu koncentracja masowa PM osiągnęła wartość maksymalną dla średnicy cząstek ok. $500 \mathrm{~nm}$ przy obciążeniu silnika $10 \mathrm{~N} \cdot \mathrm{m}$.

Zarówno przy zasilaniu silnika benzyną, jak i mieszaniną propanu i butanu dla średnicy PM ok. 110 nm wystąpiło niewielkie, lokalne maksimum masowego stężenia PM (ok. 


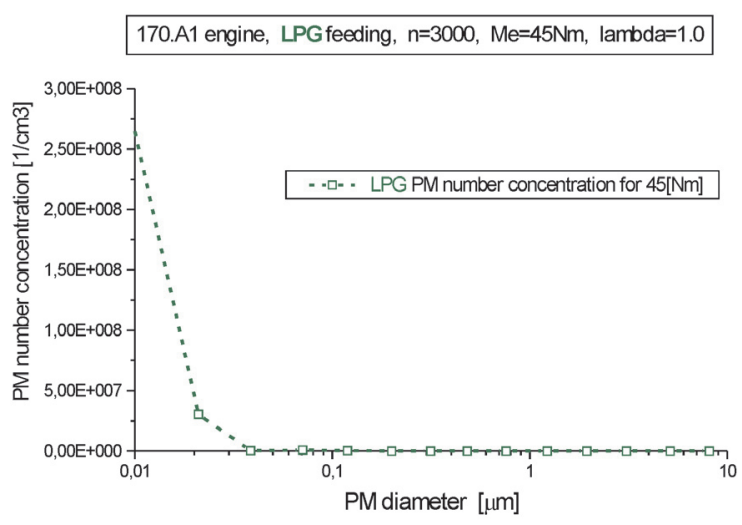

Fig. 10. PM number concentration in the exhaust gas of the 170.A1 engine fuelled with LPG related to the PM size; engine speed $n=3000$ $1 / \mathrm{min}$, load $45 \mathrm{~N} \cdot \mathrm{m}$, air excess coefficient $\lambda=1.0$

Rys. 10. Stęzenie liczbowe czastek stalych w spalinach silnika 170. Al zasilanego mieszanina propanu i butanu $w$ zależności od wielkości czastek; prędkość obrotowa silnika $n=3000 \mathrm{l} / \mathrm{min}$, obciążenie $45 \mathrm{~N} \cdot \mathrm{m}$, wspótczynnik nadmiaru powietrza $\lambda=1,0$

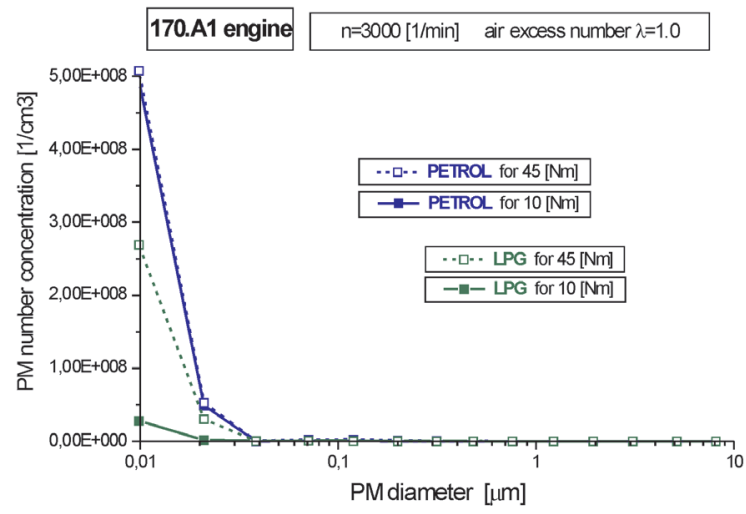

Fig. 12. Comparison of the PM number concentration in the exhaust gas of the 170.A1 engine fuelled with gasoline or LPG related to the PM size; engine speed $\mathrm{n}=3000 \mathrm{1} / \mathrm{min}$, load $10 \mathrm{~N} \cdot \mathrm{m}$ and $45 \mathrm{~N} \cdot \mathrm{m}$, air excess coefficient $\lambda=1.0$

Rys. 12. Porównanie stężenia liczbowego czqstek stalych $w$ spalinach silnika 170.A1 zasilanego benzyna lub mieszanina propanu i butanu w zależności od wielkości czastek; prędkość obrotowa silnika $n=3000$ 1/min, obciążenie $10 \mathrm{~N} \cdot \mathrm{m}$ i $45 \mathrm{~N} \cdot \mathrm{m}$, wspótczynnik nadmiaru powietrza $\lambda=1,0$

The results of the measurements of the exhaust gas components, shown in figures 14-18 had similar values for gasoline and LPG fueling. In a few cases significant differences occurred:

a) The concentration of carbon monoxide (Fig. 14) for the engine load of $45 \mathrm{~N} \cdot \mathrm{m}$ (approx. $0.47 \%$ when fueled with gasoline and approx. $0.08 \%$ when fueled with LPG),

b) The concentration of hydrocarbons (Fig. 16) for the engine load of $10 \mathrm{~N} \cdot \mathrm{m}$ (approx. $75 \mathrm{ppm}$ when fueled with gasoline and approx. $50 \mathrm{ppm}$ when fueled with LPG),

c) The concentration of oxygen (Fig. 17) for the engine load of $45 \mathrm{~N} \cdot \mathrm{m}$ (approx. $1.4 \%$ when fueled with gasoline and approx. $0.35 \%$ when fueled with LPG).

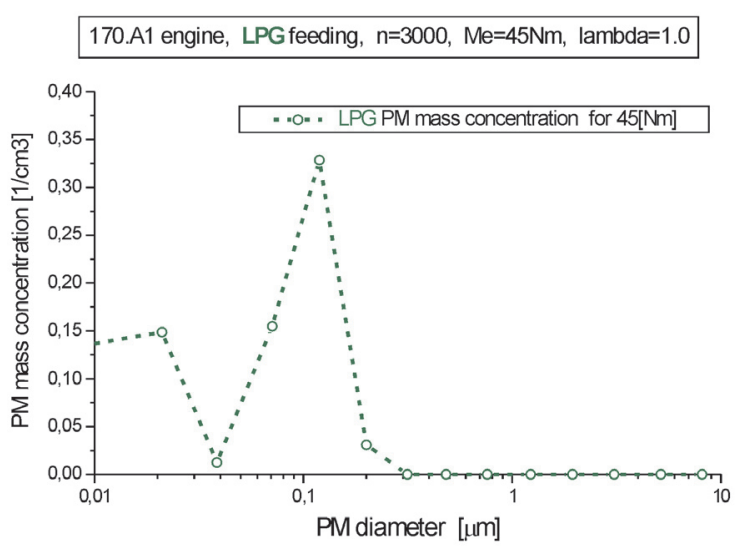

Fig. 11. PM mass concentration in the exhaust gas of the 170.A1 engine fueled with LPG related to the PM size; engine speed $n=30001 / \mathrm{min}$, load $45 \mathrm{~N} \cdot \mathrm{m}$, air excess coefficient $\lambda=1.0$

Rys. 11. Stężenie masowe cząstek statych $w$ spalinach silnika 170.A1 zasilanego mieszanina propanu i butanu w zależności od wielkości cząstek; prędkość obrotowa silnika $n=3000 \mathrm{l} / \mathrm{min}$, obciążenie $45 \mathrm{~N} \cdot \mathrm{m}$, współczynnik nadmiaru powietrza $\lambda=1,0$

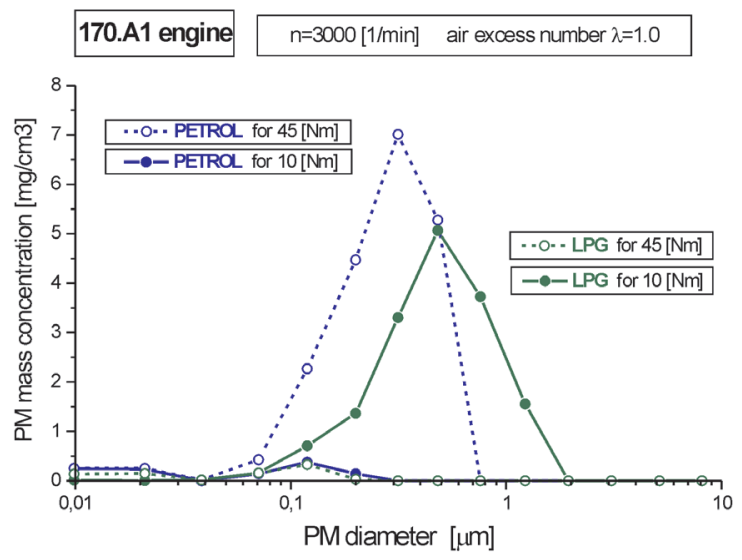

Fig. 13. Comparison of the PM mass concentration in the exhaust gas of the 170.A1 engine fueled with gasoline or LPG related to the PM size; engine speed $\mathrm{n}=3000 \mathrm{1} / \mathrm{min}$, load $10 \mathrm{~N} \cdot \mathrm{m}$ and $45 \mathrm{~N} \cdot \mathrm{m}$, air excess coefficient $\lambda=1.0$

Rys. 13. Porównanie masowego stężenia czastek statych $w$ spalinach silnika 170.A1 zasilanego benzyna lub mieszanina propanu i butanu $w$ zależności od wielkości cząstek; prędkość obrotowa silnika $n=3000$ 1/min, obciążenie $10 \mathrm{~N} \cdot \mathrm{m}$ i $45 \mathrm{~N} \cdot \mathrm{m}$, współczynnik nadmiaru powietrza

$$
\lambda=1,0
$$

$\left.0,5 \mathrm{mg} / \mathrm{cm}^{3}\right)$. Przy zasilaniu benzyną ten efekt wystąpił przy obciążeniu silnika $10 \mathrm{~N} \cdot \mathrm{m}$, natomiast przy zasilaniu mieszaniną propanu i butanu przy obciążeniu $45 \mathrm{~N} \cdot \mathrm{m}$.

Wyniki pomiarów stężenia gazowych składników spalin, przedstawione na rysunkach $14-18$, wykazały zbliżone wartości dla zasilania silnika benzyną i mieszaniną propanu i butanu. W kilku przypadkach wystąpiły jednak zauważalnie większe różnice dotyczące:

a) stężenia tlenku węgla (rys. 14) dla obciążenia silnika 45 $\mathrm{N} \cdot \mathrm{m}$ (wartość ok. 0,47 \% przy zasilaniu benzyną i ok. $0,08 \%$ przy zasilaniu mieszaniną propanu i butanu),

b) stężenia węglowodorów (rys. 16) dla obciążenia silnika $10 \mathrm{~N} \cdot \mathrm{m}$ (wartość ok. $75 \mathrm{ppm}$ przy zasilaniu benzyną i ok. $50 \mathrm{ppm}$ przy zasilaniu mieszaniną propanu i butanu), 


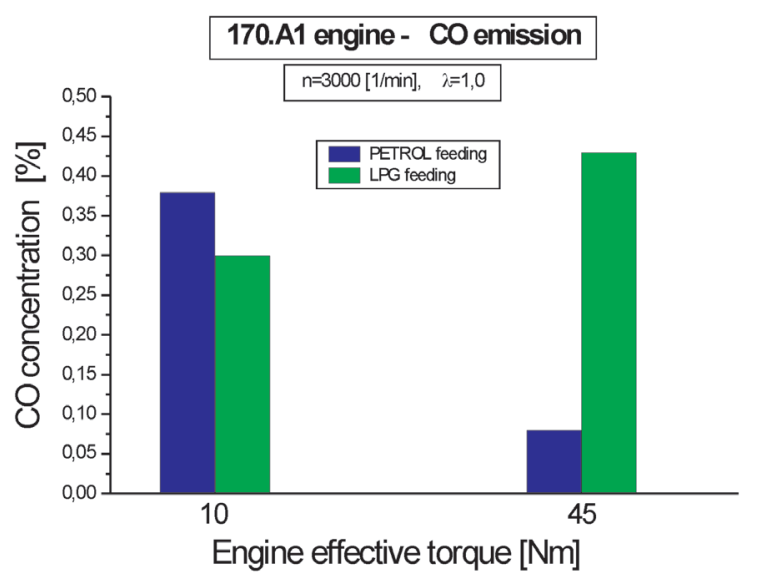

Fig. 14. Concentration of carbon monoxide in the exhaust gas of the 170.A1 engine fueled with gasoline or LPG related to the engine load; engine speed $\mathrm{n}=30001 / \mathrm{min}$, air excess coefficient $\lambda=1.0$

Rys. 14. Stężenie tlenku węgla w spalinach silnika 170.A1 zasilanego benzyna lub mieszanina propanu i butanu w zależności od obciażenia prędkość obrotowa silnika $n=3000 \mathrm{l} / \mathrm{min}$, wspótczynnik nadmiaru powietrza $\lambda=1,0$

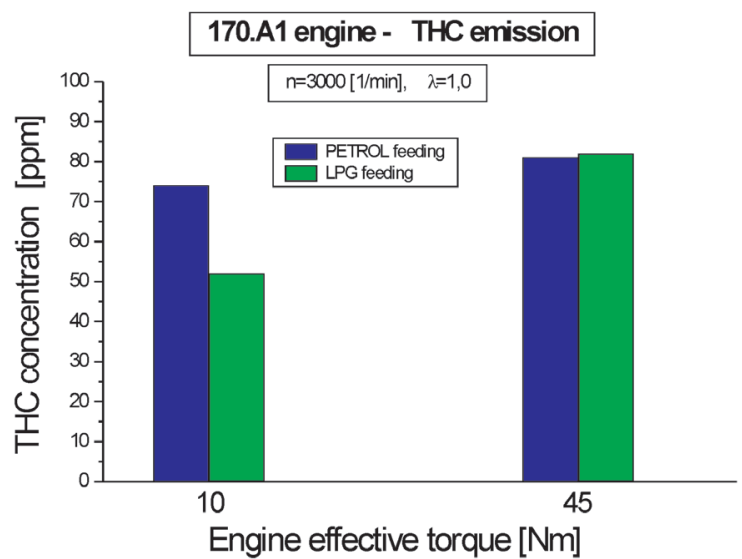

Fig. 16. Concentration of hydrocarbons in the exhaust gas of the 170.A1 engine fueled with gasoline or LPG related to the engine load; engine speed $\mathrm{n}=30001 / \mathrm{min}$, air excess coefficient $\lambda=1.0$

Rys. 16. Stężenie węglowodorów w spalinach silnika 170.A1 zasilanego benzyna lub mieszanina propanu i butanu w zależności od obcią̇enia; prędkość obrotowa silnika $n=3000 \mathrm{l} / \mathrm{min}$, wspótczynnik nadmiaru powietrza $\lambda=1,0$

\section{Analysis of the results}

The measurements have shown that in all cases of engine loads and fuel types particles of the size of 6-20 nm were the dominating fraction in the tested range of $0.006-10 \mu \mathrm{m}$.

When fueled with gasoline the concentration of the smallest particles of the diameter of 6-10 $\mathrm{nm}$ for the engine load of $10 \mathrm{~N} \cdot \mathrm{m}$ was comparable to that of the $45 \mathrm{~N} \cdot \mathrm{m}$ and was: $4.9 \mathrm{E} 81 / \mathrm{cm}^{3}$ and $5.1 \mathrm{E} 81 / \mathrm{cm}^{3}$ respectively.

The extreme values of the particle number concentration of the nanoparticles in this diameter range (Fig. 12) are as reported in literature [4]. Special investigations are to be conducted to determine their structure and chemical composition.

When fueled with LPG the mass concentration of particles of the diameter of 6-10 $\mathrm{nm}$ for the engine load of 10

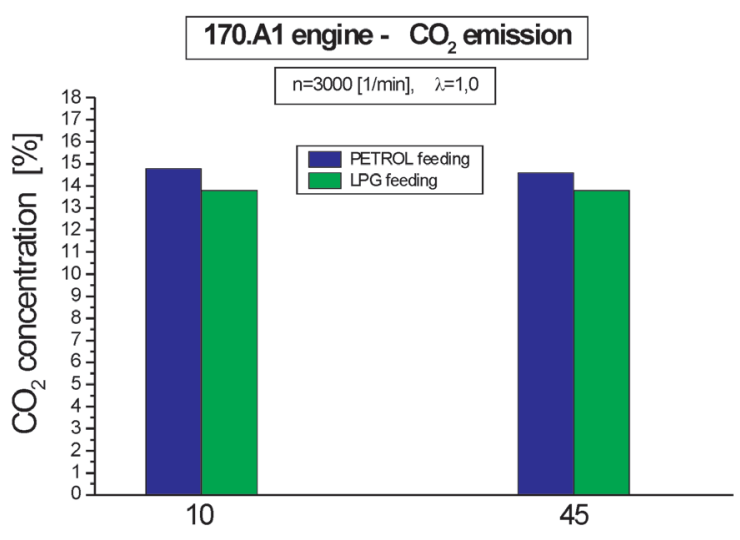

Engine effective torque [Nm]

Fig. 15. Concentration of carbon dioxide in the exhaust gas of the 170

A1 engine fueled with gasoline or LPG related to the engine load; engine speed $\mathrm{n}=30001 / \mathrm{min}$, air excess coefficient $\lambda=1.0$

Rys. 15. Stężenie dwutlenku węgla w spalinach silnika 170.A1 zasilanego benzyna lub mieszanina propanu i butanu $w$ zależności od obciażenia; prędkość obrotowa silnika $n=3000$ 1/min, współczynnik nadmiaru powietrza $\lambda=1,0$

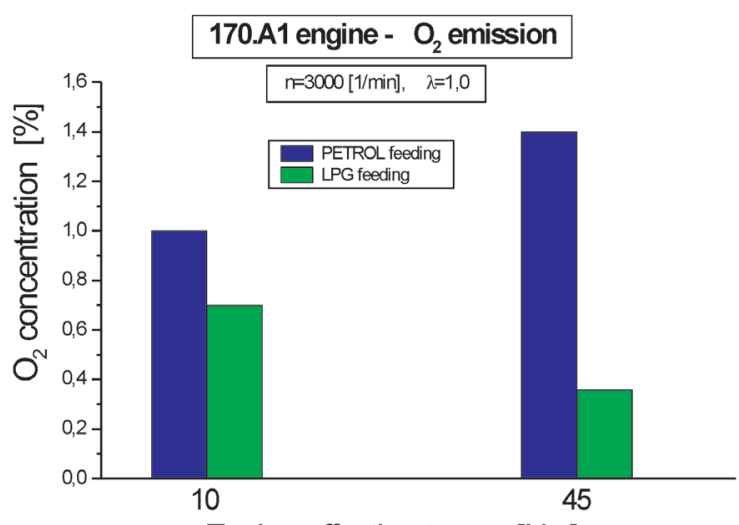

Fig. 17. Concentration of oxygen in the exhaust gas of the 170.A1 engine fueled with gasoline or LPG related to the engine load; engine speed $\mathrm{n}=30001 / \mathrm{min}$, air excess coefficient $\lambda=1.0$

Rys. 17. Stężenie tlenu w spalinach silnika 170.A1 zasilanego benzyna lub mieszanina propanu i butanu w zależności od obciązenia; prędkość obrotowa silnika $n=3000 \mathrm{l} / \mathrm{min}$, współczynnik nadmiaru powietrza $\lambda=1,0$

c) stężenia tlenu (rys. 17) dla obciążenia silnika $45 \mathrm{~N} \cdot \mathrm{m}$ (wartość ok. 1,4\% przy zasilaniu benzyną i ok. 0,35\% przy zasilaniu mieszaniną propanu i butanu).

\section{Analiza wyników badań}

Przeprowadzone pomiary wykazały, że we wszystkich przypadkach obciążenia silnika i rodzaju paliwa cząstki o rozmiarze z przedziału 6-20 $\mathrm{nm}$ stanowiły frakcję liczebnie dominującą w badanym zakresie $0,006-10 \mu \mathrm{m}$.

Przy zasilaniu benzyną koncentracja najmniejszych PM o średnicy $6-10 \mathrm{~nm}$ dla obciążenia silnika $10 \mathrm{~N} \cdot \mathrm{m}$ była porównywalna $\mathrm{z}$ koncentracją $\mathrm{PM}$ dla obciążenia $45 \mathrm{~N} \cdot \mathrm{m}$ i wynosiła odpowiednio około: 4,9E8 1/ $\mathrm{cm}^{3}$ i 5,1E8 1/ $\mathrm{cm}^{3}$.

Ekstremum wartości liczbowego stężenia nanocząstek 
$\mathrm{N} \bullet \mathrm{m}$ was approximately $2.8 \mathrm{E} 71 / \mathrm{cm} 3$ and was one order of magnitude smaller than for the load of $45 \mathrm{~N} \cdot \mathrm{m}$ (approximately $2,7 \mathrm{E} 81 / \mathrm{cm}^{3}$ ). Such a relation was expected as it was assumed that greater loads should generate a greater number of particles.

The mass of the generated particles, when fueled with gasoline as well as LPG (Fig. 13) was formed by particles form the range $100-1000 \mathrm{~nm}$.

The maximum of the particle mass, when fueled with gasoline, was for particles of the diameter of approximately $300 \mathrm{~nm}$ and the concentration of the particle mass was approximately $7 \mathrm{mg} / \mathrm{cm}^{3}$.

LPG fueling resulted in shifting of this maximum towards greater particles - up to approximately $500 \mathrm{~nm}$ but the maximum value of the mass concentration of the particles ( 5 $\left.\mathrm{mg} / \mathrm{cm}^{3}\right)$ was recorded for the lower engine load $(10 \mathrm{~N} \cdot \mathrm{m})$. This result was rather unexpected.

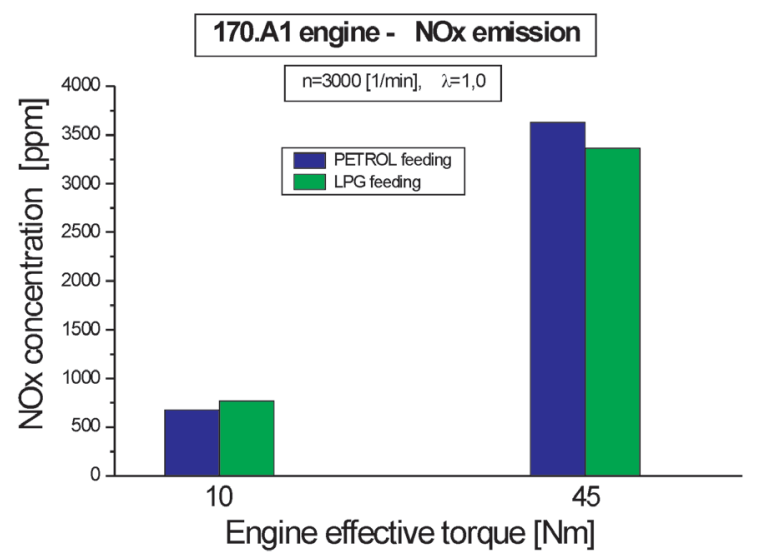

Fig. 18. Concentration of nitric oxides (NOx) in the exhaust gas of the 170.A1 engine fueled with gasoline or LPG related to the engine load; engine speed $\mathrm{n}=30001 / \mathrm{min}$, air excess coefficient $\lambda=1.0$

Rys. 18. Stężenie tlenków azotu w spalinach silnika 170.A1 zasilanego benzyna lub mieszanina propanu i butanu w zależności od obciążenia; prędkość obrotowa silnika $n=30001 /$ min, współczynnik nadmiaru powietrza $\lambda=1,0$

An indirect explanation may be given by the analysis of the results of simultaneously conducted measurements of the exhaust components concentration shown in Fig. 14-18. Comparing the tracings of the particle mass concentration (Fig. 13) with the tracing of the concentration of carbon monoxide (Fig. 14) and oxygen concentration (Fig. 17) we may notice a relationship among these quantities. The lower the emission of carbon monoxide and greater of oxygen, the greater the recorded mass concentration of particulate matter. If more carbon atoms are bonded in a reaction of incomplete combustion - fewer free atoms may form particulate matter. Most likely, the source of such relations among the said compounds in the exhaust lies in the mere combustion process of the applied fuels.

The tracings of the concentration of the exhaust gas components (Figs. 14-18) do not provide sufficient information to assess the influence of the lubricant or mineral particles w tym zakresie wymiarów (rys. 12) jest zgodne z tendencją opisaną w literaturze [4]. Należy jednak przeprowadzić specjalne badania w celu określenia ich budowy i składu chemicznego.

Przy zasilaniu silnika mieszaniną propanu i butanu koncentracja masowa PM o średnicy 6-10 nm dla obciążenia silnika $10 \mathrm{~N} \cdot \mathrm{m}$ wynosiła około $2,8 \mathrm{E} 71 / \mathrm{cm}^{3}$ i była o rząd wielkości mniejsza niż dla obciążenia $45 \mathrm{~N} \cdot \mathrm{m}$, kiedy wynosiła około $2,7 \mathrm{E} 81 / \mathrm{cm}^{3}$. Taka zależność była zgodna z oczekiwaniem, gdyż uznano, że większe obciążenie powinno generować większą liczbę PM.

Masa emitowanych PM zarówno przy zasilaniu benzyną, jak i mieszaniną propanu i butanu (rys. 13), tworzona była przez cząstki o średnicy z przedziału 100-1000 nm.

Maksimum masy PM w przypadku zasilania silnika benzyną przypadało na cząstki o średnicy ok. $300 \mathrm{~nm}$, a wartość koncentracji masy cząstek wynosiła ok. $7 \mathrm{mg} / \mathrm{cm}^{3}$.

Zasilanie mieszaniną propanu i butanu powodowało przesunięcie tego maksimum w kierunku większych PM - do ok. $500 \mathrm{~nm}$, ale maksymalną wartość koncentracji masy cząstek $\left(5 \mathrm{mg} / \mathrm{cm}^{3}\right)$ zarejestrowano dla mniejszego obciążenia silnika $(10 \mathrm{~N} \cdot \mathrm{m})$. Ten wynik należy uznać za nieoczekiwany.

Pośrednie wyjaśnienie może przynieść analiza wyników równolegle prowadzonych pomiarów stężenia gazowych składników spalin przedstawionych na rys. 14-18. Porównując wykresy masowego stężenia cząstek stałych (rys. 13) z przebiegami stężenia tlenku węgla (rys. 14) oraz stężenia tlenu (rys. 17), można zauważyć związek między tymi wielkościami. Im mniejsza jest emisja tlenku węgla, a większa emisja tlenu, tym większe zarejestrowane masowe stężenie cząstek stałych. Jeżeli więcej atomów węgla zostaje związanych w reakcji niezupełnego spalania - mniej wolnych atomów może tworzyć cząstki stałe. Najprawdopodobniej źródło takich zależności między wymienionymi związkami w spalinach silnika leży w samym procesie spalania zastosowanych paliw.

Wykresy stężenia gazowych składników spalin (rys. 14 18) nie dostarczają wystarczającego materiału do oceny wpływu oleju smarującego lub cząstek mineralnych zasysanych z otoczenia na zmierzoną emisję cząstek stałych. Ocena taka byłaby możliwa jedynie na podstawie specjalnych badań.

\section{Podsumowanie i wnioski}

W artykule przedstawiono wyniki badań emisji cząstek stałych w spalinach silnika ZI zasilanego benzyną lub skroploną mieszaniną propanu i butanu. Badania wykonano na czterocylindrowym silniku 170.A1 o objętości skokowej $0,9 \mathrm{dm}^{3}$, przy stałej prędkości obrotowej wału korbowego $\mathrm{n}=30001 / \mathrm{min}$, dla dwóch stanów obciążenia: $10 \mathrm{~N} \cdot \mathrm{m}$ i $45 \mathrm{~N} \cdot \mathrm{m}$.

Analiza uzyskanych wyników umożliwia sformułowanie następujących wniosków dotyczących emisji cząstek stałych w spalinach badanego silnika ZI:

- dominującą liczebnie frakcję stanowiły najmniejsze cząstki stałe o średnicy 6-20 nm zarówno przy zasilaniu benzyną, jak i mieszaniną propanu i butanu; określenie składu i budowy tych cząstek wymaga przeprowadzenia specjalnych badań, 
sucked in from the ambient air on the measured PM emission. Such an assessment would only be possible following special investigations.

\section{Conclusions}

In the paper, the author presented the results of investigations on the emission of particulate matter in the exhaust gas from a spark ignition engine fueled with gasoline or LPG. The investigations were performed on a 170.A1 four cylinder $0.9 \mathrm{dm}^{3}$ engine at a constant speed of $\mathrm{n}=3000$ $1 / \mathrm{min}$ for two loads: $10 \mathrm{~N} \cdot \mathrm{m}$ and $45 \mathrm{~N} \cdot \mathrm{m}$.

The analysis of the obtained results allows formulating the following conclusions related to the emission of PM from a spark ignition engine:

- the dominating fraction were the smallest particles of the diameter of 6-20 nm when fueled with gasoline as well as LPG; the determination of the structure and chemical composition of these particles requires separate investigations,

- the emitted PM mass was chiefly formed by greater particles of the diameter $100-1000 \mathrm{~nm}(0.1-1 \mu \mathrm{m})$ and the maximum of the mass concentration of PM occurred for the diameter range of PM 300-500 nm,

- a relation between the mass concentration of PM and the concentration of carbon monoxide and oxygen in the exhaust gas has been observed; the greater the concentration of carbon monoxide (lower oxygen concentration) the smaller the PM mass,

- the source of the differences in the PM emission lies in the mere combustion process of the fuels used for the tests,

- the determination of the influence of the lubricant or mineral particles sucked in from the ambient air on the emission of PM requires research that would enable physicochemical analysis of the particles.

The confirmation of the correctness of the above reasoning requires investigations based on a procedure that tackles the subject matter more comprehensively.

Jerzy Dutczak, DEng. - doctor in the Chair of Combustion Engines, Institute of Automobiles and Internal Combustion Engines at Cracow University of Technology. Dr inż. Jerzy Dutczak - adiunkt w Zakładzie Silników Spalinowych Instytutu Pojazdów Samochodowych i Silników Spalinowych Politechniki Krakowskiej. e-mail:jdutczak@usk.pk.edu.pl
- emitowana masa PM tworzona była głównie przez cząstki większe o średnicy z przedziału 100-1000 nm $(0,1-1 \mu \mathrm{m})$, przy czym maksimum masowej koncentracji PM występowało $\mathrm{w}$ przedziale średnic PM $300-500 \mathrm{~nm}$,

- zauważono związek między masowym stężeniem PM a stężeniem tlenku węgla i tlenu w spalinach; im większe stężenie tlenku węgla (a mniejsze stężenie tlenu), tym mniejsza masa PM,

- źródło różnic w emisji PM leży prawdopodobnie w samym procesie spalania badanych paliw,

- określenie wpływu oleju smarującego lub cząstek mineralnych zasysanych z otoczenia na emisję PM wymaga przeprowadzenia badań umożliwiających analizę fizykochemiczną cząstek.

Potwierdzenie słuszności powyższego wnioskowania wymaga przeprowadzenia w przyszłości badań opartych na procedurze szerzej ujmującej przedmiotowe zagadnienie.

\section{Bibliography/Literatura}

[1] Commision Regulation (EC) No 692/2008 of 18 July 2008 of the European Parliament and of the Council on type-approval of motor vehicles with respect to emissions from light passenger and commercial vehicles (Euro 5 and Euro 6) and on access to vehicle repair and maintenance information. Official Journal of the European Union, L 199, 1-136, 28.07.2008.

[2] Dutczak J.: Non-standard applications of the Horiba TEOM 1105 analyser. Combustion Engines. 2013, 154(3), 670-676. ISSN 0138-0346.

[3] Materiały informacyjne firmy Dekati Ltd. Finland. http://www. dekati.fi.

[4] Kittelson D.B.: Engines and Nanoparticles: A Review. Journal of Aerosol Science 29, 1998, 575-588.

[5] Bielaczyc P., Czerwinski J., Woodburn J.: Current trends in measurement and control of particle emissions from engines (perspectives from the 1st Workshop on Particulate Matter Emissions from Engine and Automobile Sources, 2 July 2012, Bielsko-Biala, Poland). Combustion Engines. 2012, 150, 89-95. ISSN 0138-0346.

[6] Kittelson D.B., Watts W.F., Johnson J.P., Schauer J.J., Lawson D.R.: On-road and laboratory evaluation of combustion aerosols - part 2: Summary of spark ignition engine results. Journal of Aerosol Science 37. 2006. 931-949.

[7] Kittelson D.B., Zheng Z., Johnson K.C., Liu Z., Durbin T.D., Hu S., Huai T., Jung H.S.: Investigation of solid particle number measurement: Existence and nature of sub-23 nm particles under PMP methodology. Journal of Aerosol Science 42. 2011, 883-897.

[8] Arsie I., Di Iorio S., Vaccaro S.: Experimental investigation of the effects of AFR, spark advance and EGR on nanoparticle emissions in a PFI SI engine. Journal of Aerosol Science 64. 2013, 1-10.

[9] Ding L., Chan T.W., Ke F., Wang D.K.W.: Characterization of chemical composition and concentration of fine particulate matter during a transit strike in Ottawa, Canada. Atmospheric Environment 89. 2014, 433-442. 